\title{
Amperometric detection of triclosan with screen-printed carbon nanotube electrodes modified with Guinea Grass (Panicum maximum) peroxidase
}

\author{
Angie E. Orduz ${ }^{1}$, Jorge A. Gutiérrez ${ }^{2}$, Sergio I. Blanco ${ }^{3}$, John J. Castillo, ${ }^{1, *}$
}

\section{Edited by \\ Juan Carlos Salcedo-Reyes \\ (salcedo.juan@javeriana.edu.co) \\ 1. Escuela de Química, Grupo de investigación en Bioquímica y Microbiología (GIBIM), \\ Universidad Industrial de Santander, Bucaramanga, Colombia. \\ 2. Programa de Seguridad y Salud en el trabajo, Facultad de Ciencias de la Salud, Universidad del Quindío \\ 3. Escuela de Ingeniería Metalúrgica, Universidad Industrial de Santander, Bucaramanga, Colombia. \\ * jcasleon@uis.edu.co}

Received: 05-03-2018

Accepted: 16-01-2019

Published on line: 08-08-2019

Citation: Orduz AE, Gutiérrez JA, Blanco SI, Castillo JJ. Amperometric detection of triclosan with screen-printed carbon nanotube electrodes modified with Guinea Grass (Panicum maximum) peroxidase, Universitas Scientiarum, 24 (2): 363-379, 2019 doi: 10.11144/Javeriana.SC24-2.adot

Funding:

Universidad Industrial de SantanderVicerrectoría de Investigación y Extensión.

Electronic supplementary material: Suppl. 1 - 2

OPEN ACCESS

\begin{abstract}
Triclosan is a compound with antimicrobial activity broadly used in consumer products. Because of its well-documented toxicity, the amount of triclosan present in different products needs to be tightly controlled. This paper outlines a new amperometric sensor for triclosan detection consisting of a screen-printed carbon nanotube electrode (SPCNE) modified with Guinea grass peroxidase (GGP). The GGP-modified SPCNE was able to detect an enhanced electrochemical response of triclosan, unlike the bare SPCNE. The cyclic voltammograms of the GGP-modified SPCNE in a solution of potassium ferrocyanide showed an increase in the current values and linearity between scan rates and oxidation peak currents, suggesting a surface-controlled process. The GGP-modified SPCNE showed an excellent electrocatalytic activity to triclosan oxidation, at a redox potential of $370 \mathrm{mV}$, in the presence of hydrogen peroxide, exhibiting a linear response between $20 \mathrm{mM}$ to $80 \mathrm{mM}$ and a detection limit of $3 \mu \mathrm{M}$. This new amperometry system, based on carbon nanotubes integrated with GGP, becomes a potential tool for environmental analysis and food quality control.
\end{abstract}

Keywords: amperometric biosensor; carbon nanotubes; guinea grass peroxidase; screen printed electrodes; triclosan.

\section{Introduction}

Triclosan (TCS) is an antibacterial and antifungal molecule present in consumer products, such as toothpaste, soap, detergents, and surgical cleaners (Lenz et al., 2017). TCS has been reported to be a precursor of substances such as dioxins, which are extremely toxic. TCS role as an endocrine disruptor has been revealed (Ozaki et al., 2017). Because of accumulation and biomagnification of TCS in water, this compound can ultimately be consumed by humans. Due to its harmful effects, TCS has been considered as a high priority pollutant and its presence in household products should not exceed $0.3 \%(\mathrm{w} / \mathrm{w})$. 
Different methods have been reported to detect TCS, including liquid chromatography (Guo et al., 2009), chemiluminescence (Song et al., 2007), and gas chromatography coupled to mass spectrometry (Shi et al., 2013). Although the effectiveness and robustness of these methods are indisputable, they are expensive, complex, and time-consuming. Therefore, developing novel, straightforward, and sensitive methods for TCS detection will expedite routine chemical analyses.

Electrochemical methods are attractive (due to their simplicity, rapidity, and convenience) for the development of enzymatic biosensors to detect environmental and biomedical analytes (Rotariu et al., 2016). Recently, a novel technology based on screen-printed electrodes (SPE) has been implemented in many bioanalytical applications. For example, an SPE was developed to detect TCS by cyclic voltammetry (Yang et al., 2009). SPE technology offers some advantages over traditional electrodes regarding cost, solution volume, and operation temperatures.

TCS molecules contain an electrochemically and easily oxidizable phenolic group, as shown in Fig. 1. This phenolic group can be more readily oxidized in the presence of peroxidases (EC 1.11.1.7). Peroxidases are enzymes able to catalyze the oxidation of different amines and phenols using $\mathrm{H}_{2} \mathrm{O}_{2}$ (Sakharov et al., 2003, Besharati et al., 2018, Alemzadeh et al., 2009). Due to its broad affinity for phenolic compounds, horseradish peroxidase (HRP) is the most commonly employed redox enzyme in the fabrication of amperometric biosensors (Wang et al., 2012). However, a recent study showed that HRP exhibited a low activity on aniline oxidation, and that it is unstable at $\mathrm{pH}<4.5$ during the synthesis of polyaniline (Sakharov et al., 2003). Therefore, new plant peroxidases are needed that do not have the limitations of HRP. The

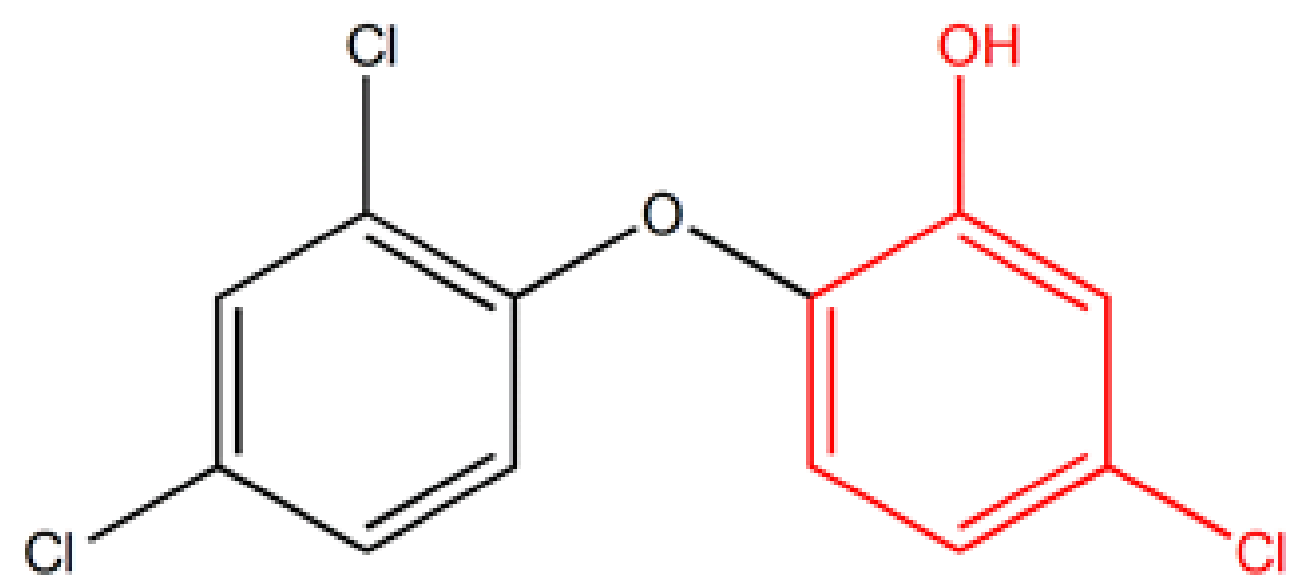

Figure 1. Molecular structure of triclosan, emphasizing its phenolic group (in red). 
guinea grass (Panicum maximum) peroxidase (GGP) was recently semi-purified and characterized (Centeno et al., 2017). Remarkably, the GGP exhibited greater resistance to high concentrations of hydrogen peroxide and was less $\mathrm{pH}$ - and temperature-sensitive than commercial HRP.

Different authors have reported the use of electrochemical sensors for the determination of TCS. Screen-printed carbon electrodes have been prepared using different electroanalytical techniques and nanomaterials (Li et al., 2014). Dai et al., (2012) employed glassy carbon electrodes modified with carbon nanodots and chitosan to construct a TCS sensor, and Yang et al., (2009) used multiwall carbon nanotube films to fabricate an electrochemical sensor for rapid TCS detection. Recently, Wu et al., (2017) prepared a hybrid between palladium and graphene nanoparticles to develop an electrochemical TCS detector. An analytical method based on the effect of sodium dodecyl sulfate (SDS) on the voltammetric behavior of TCS was developed to determine TCS

traces with promising results (Fotouhi et al., 2010). Notwithstanding, none of these previous studies has explored the possibility of determining TCS using enzymatic sensors, nor have they considered the use of screen-printed carbon nanotube electrodes (SPCNE) modified with GGP.

Aiming at creating an analytical tool for the rapid determination of TCS in samples of environmental importance, in this work we describe the construction of an amperometric biosensor based on the modification of SPCNE with GGP using N-(3-Dimethylaminopropyl)-N-ethylcarbodiimide (EDC) as a linking agent. We employed cyclic voltammetry and chronoamperometric methods to characterize the biosensor's electrodes, and we tested the modified SPCNE detecting $\mathrm{H}_{2} \mathrm{O}_{2}$ and TCS. Finally, we determined the biosensor's analytical parameters such as its limit of detection (LOD), linear range, and sensibility.

\section{Materials and methods}

\section{Extraction and purification of guinea grass peroxidase}

Leaves of Guinea grass (Panicum maximum) were collected from pastures in the region of Santander, Colombia. First, all collected leaves were cut in small pieces $(5 \mathrm{~cm})$ and washed in $30 \mathrm{mM}$ of phosphate buffered saline (PBS), $\mathrm{pH}$ 8.0. The extracts obtained were treated with polyethylene glycol and ammonium sulphate $\left(\left(\mathrm{NH}_{4}\right)_{2} \mathrm{SO}_{4}\right)$ in order to make a two-phase system; then, the aqueous phase containing the GGP was semi-purified by gel permeation chromatography with a Sephadex G-50 column calibrated with 
a TRIS buffer $3 \mathrm{mM}, \mathrm{pH}$ 7.5. Under these conditions, the GGP extract was adsorbed on the Sephadex G-50 column and eluted with TRIS buffer. Finally, the elution containing the peroxidase was collected and concentrated by ultracentrifugation.

\section{Enzyme activity}

GGP activity was measured by UV-vis spectroscopy, as follows: $10 \mu \mathrm{L}$ of the enzyme was added to $2.5 \mathrm{~mL}$ of $30 \mathrm{mM}$ PBS of pH 8.0 containing $10 \mathrm{mM}$ guaiacol and $4.4 \mathrm{mM} \mathrm{H}_{2} \mathrm{O}_{2}$ as substrates (Centeno et al., 2017). The increase in absorbance values was monitored at $25^{\circ} \mathrm{C}$ (guaiacol $\left.=5200 \mathrm{M} \cdot \mathrm{cm}^{-1}\right)$. Activity $(\mathrm{U})$ was defined as the amount of GGP that produced the modification of $1 \mu$ mole of guaiacol in one minute. The specific activity is expressed as units of activity per $\mathrm{mg}$ of protein. The amount of protein was determined by the Bradford method (Bradford et al., 1976) as described in Centeno et al., (2017).

Modification of the screen-printed carbon nanotube electrode

To modify the SPCNE, $4 \mu \mathrm{L}$ of a $25 \mathrm{mM}$ EDC (1-ethyl-3[3-dimethylaminopropyl] carbodiimide hydrochloride) solution were placed onto the electrode's surface. EDC is a carbodiimide that enables the conjugation of proteins containing carboxyl groups with amines. In the present study, EDC was used as a coupling agent to mediate the formation of links between the carboxyl group of the electrode's carbon nanotubes and the amine groups of the GGP. Next, $6 \mu \mathrm{L}$ of GGP were added onto the EDC-modified SPCNE surface. After incubation at $4^{\circ} \mathrm{C}$ for 4 hours, the modified electrode was washed with phosphate buffer to eliminate any excess of EDC or GGP. A schematic of the SPCNE modification with GGP and the electrochemical TCS detection is shown in Suppl. 1.

\section{Electrochemical procedures}

Electro-analytical measurements were performed with an Autolab PGSTAT101 device (Echo Chemie, Utrecht, the Netherlands) run by the NOVA 1.10.1.9 software (Metrohm, Filderstadt, Germany). Screen-printed carbon nanotube electrodes modified with carboxyl-functionalized single-walled carbon nanotubes (SPCNE, 110SWCNT) were obtained from DropSens (Oviedo, Spain). Carboxyl functional groups on the surface of the electrodes were modified by the enzyme's amine groups. These screen-printed electrodes (consistingconsisting of a working electrode of $4 \mathrm{~mm}$ in diameter, a silver rod pseudoreference electrode, and an auxiliary carbon electrode) were composed of single-walled carbon nanotubes. The GGP-modified SPCNE was 
fitted into a methacrylate electrochemical cell of $5 \mathrm{~mL}$ of volume (DropSens, Oviedo, Spain). Cyclic voltammetry experiments were carried out at $27^{\circ} \mathrm{C}$ in different solutions. Before each cyclic voltammetry experiment, the solutions were freed of oxygen bubbles through degasification with $\mathrm{N}_{2}$ and magnetic stirring for $30 \mathrm{~s}$.

For the chronoamperometric experiments, the potential was set at $370 \mathrm{mV}$ (vs $\mathrm{Ag}$ ) and the solution was magnet-stirred before and during the addition of $10 \mu \mathrm{L}$ of a $5 \mathrm{mM}$ TCS$-\mathrm{H}_{2} \mathrm{O}_{2}$ solution. All the applied potentials used in this study are referred to the SPCNE's internal silver pseudoreference electrode. Using the GGP-modified electrode, the effects of potentially interfering compounds, namely o-nitrophenol, ascorbic acid, and glucose, were evaluated under optimized experimental conditions. Possible changes in the current signal of two TCS test solutions ( 1 and $2 \mathrm{mM}$ ) during the sequential addition of each interfering compound were evidenced by comparing the resulting chronoamperometric response to that obtained in a TCS solution without the addition of any of these compounds.

Analysis of TCS dissolved in tap water

Three different GGP-modified SPCNEs were employed to detect TCS in different concentrations $(5 \mu, 12 \mu$, and $22 \mu \mathrm{M})$ in tap water samples. The potential was set at $370 \mathrm{mV}$ (vs Ag), as previously determined by the cyclic voltammetry experiments.

\section{Results and Discussion}

GGP partial purification results are summarized in Table 1. The obtained guinea grass extract was rich in pigments that were efficiently removed by extraction in an aqueous bi-phasic system formed by PEG-( $\left.\mathrm{NH}_{4}\right)_{2} \mathrm{SO}_{4}$. Subsequent Sephadex-based elution and concentration steps yielded a partially purified GGP with a specific activity of $609 \mathrm{U} \mathrm{mg}^{-1}$ of protein.

The cyclic voltammograms obtained from unmodified SPCNEs and GGP-modified SPCNEs in a potassium ferrocyanide $\left(\mathrm{K}_{3} \mathrm{Fe}(\mathrm{CN})_{6}\right)$ solution are shown in Fig. 2A. The Cyclic voltammogram of the unmodified electrode revealed a redox process of the ferri/ferrocyanide couple. Whereas, the cyclic voltammogram plot of the GGP-modified electrode showed an increase in both anodic and cathodic current peaks (Fig 2A), suggesting that the added peroxidase is important in the electronic communication between redox species and the electrode's surface.

voltammetry analysis of the electrochemical responses of the GGP-modified SPCNE in three solutions: $\mathrm{H}_{2} \mathrm{O}_{2}$, TCS, and $\mathrm{H}_{2} \mathrm{O}_{2}+$ TCS are shown in Fig. 2B. The cyclic voltammetry plot of the GGP-modified SPCNE in the 
Table 1. Partial purification of the peroxidase from guinea grass leave extract.

\begin{tabular}{|c|c|c|c|c|c|c|}
\hline Step & $\begin{array}{l}\text { Volume } \\
(\mathrm{mL})\end{array}$ & $\begin{array}{l}\text { Protein } \\
\text { (mg) }\end{array}$ & $\begin{array}{l}\text { Total } \\
\text { activity } \\
\text { (U) }\end{array}$ & $\begin{array}{l}\text { Specific } \\
\text { activity } \\
\left(\mathrm{U} \mathrm{mg}^{-1}\right)\end{array}$ & $\begin{array}{l}\text { Yield } \\
(\%)\end{array}$ & $\begin{array}{l}\text { Purification } \\
\text { fold }\end{array}$ \\
\hline Initial extraction & 130 & 60 & 11765 & 198 & 100 & 1 \\
\hline Pigment extraction & 59 & 26 & 11660 & 444 & 98 & 2.2 \\
\hline $\begin{array}{l}\text { Gel permeation } \\
\text { chromatography }\end{array}$ & 18 & 11 & 2822 & 249 & 24 & 1.2 \\
\hline Ultracentrifugation & 9 & 4 & 2452 & 609 & 20 & 3 \\
\hline
\end{tabular}

$\mathrm{H}_{2} \mathrm{O}_{2}$ solution (Fig. 2B, red curve) exhibited a cathodic current signal around $-791 \mathrm{mV}$ due to the bio-electrocatalytic reduction of $\mathrm{H}_{2} \mathrm{O}_{2}$ mediated by the peroxidase (Centeno et al., 2017). The cyclic voltammetry response of the GGP-modified SPCNE in the TCS solution (Fig. 2B, black curve) revealed an oxidation current at $370 \mathrm{mV}$. This may be due to the GGP's heme group onto the electrode's surface electrocatalyzing the phenoxy group of the TCS molecules (Brusova et al., 2005). For the $\mathrm{H}_{2} \mathrm{O}_{2}+$ TCS solution, the
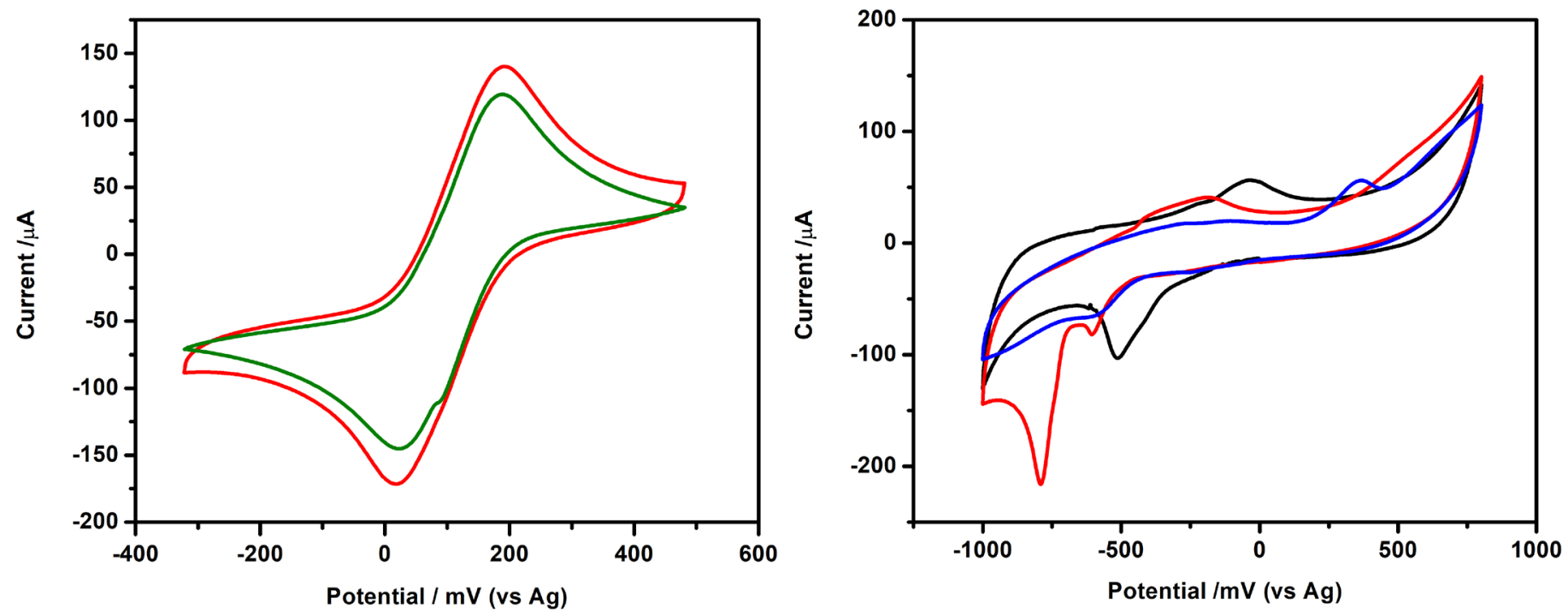

Figure 2. (A) Cyclic voltammograms of a bare SPCN electrode (green) and a GGP-modified SPCN electrode (red) in the presence of $10 \mathrm{Mm} \mathrm{K}_{3} \mathrm{Fe}(\mathrm{CN})_{6}$, scan rate $100 \mathrm{mVs}^{-1}$. (B) Cyclic voltammograms of a GGP-modified SPCN electrode in three different solutions: $\mathrm{H}_{2} \mathrm{O}_{2} 5 \mathrm{mM}$ (red line), TCS $1 \mathrm{mM}$ (black line), and $\mathrm{H}_{2} \mathrm{O}_{2} 5 \mathrm{mM}+$ TCS $1 \mathrm{mM}$ (blue line). 
GGP-modified SPCNE revealed a well-defined redox peak around -31 and -427 $\mathrm{mV}$ (Fig, 2B; blue curve) attributed to the iron present in the GGP's heme group (Brusova et al., 2005, Gaspar et al., 2000). Similar studies have reported oxidation potentials close to the value obtained in this work (Wu et al., 2017, Fotohui et al., 2010). Based on this result, we can suggest that the carbon nanotube electrode modified with the GGP can be used as a potential bioanalytical device to detect TCS.

When the GGP-modified SPCNE was tested with 0.03 M PBS (pH 8.0) at scan rates, ranging from 40 to $150 \mathrm{mVs}-1$, both anodic and cathodic current peaks increased linear to the scan rate root, producing diffusion of redox species to the electrode (Fig. 3). This behavior is related with the kinetics of the reactions, suggesting a diffusion controlled and quasi-reversible process (Huang et al., 2009).

$\mathrm{pH}$ influenced the bio electrooxidation current of TCS (Fig. 4). At $\mathrm{pH}<6$, the relative current decreased in approximately $60 \%$ suggesting that the peroxidase is inactivated either by the stability of charges or by loss of its tertiary structure. In the $\mathrm{pH}$ range between 6 and 8 , the bioelectrocatalytic activity of the GGP in the presence of TCS increased more than $50 \%$ of the relative current, and in the $\mathrm{pH}$ range of 8 to 10 , the increase in GGP bioelectrocatalytic activity was less pronounced. Altogether, in the $\mathrm{pH}$ range from 6 to 10, the enzyme exhibited a better electrocatalytic response, reaching its maximum at $\mathrm{pH} 10$.
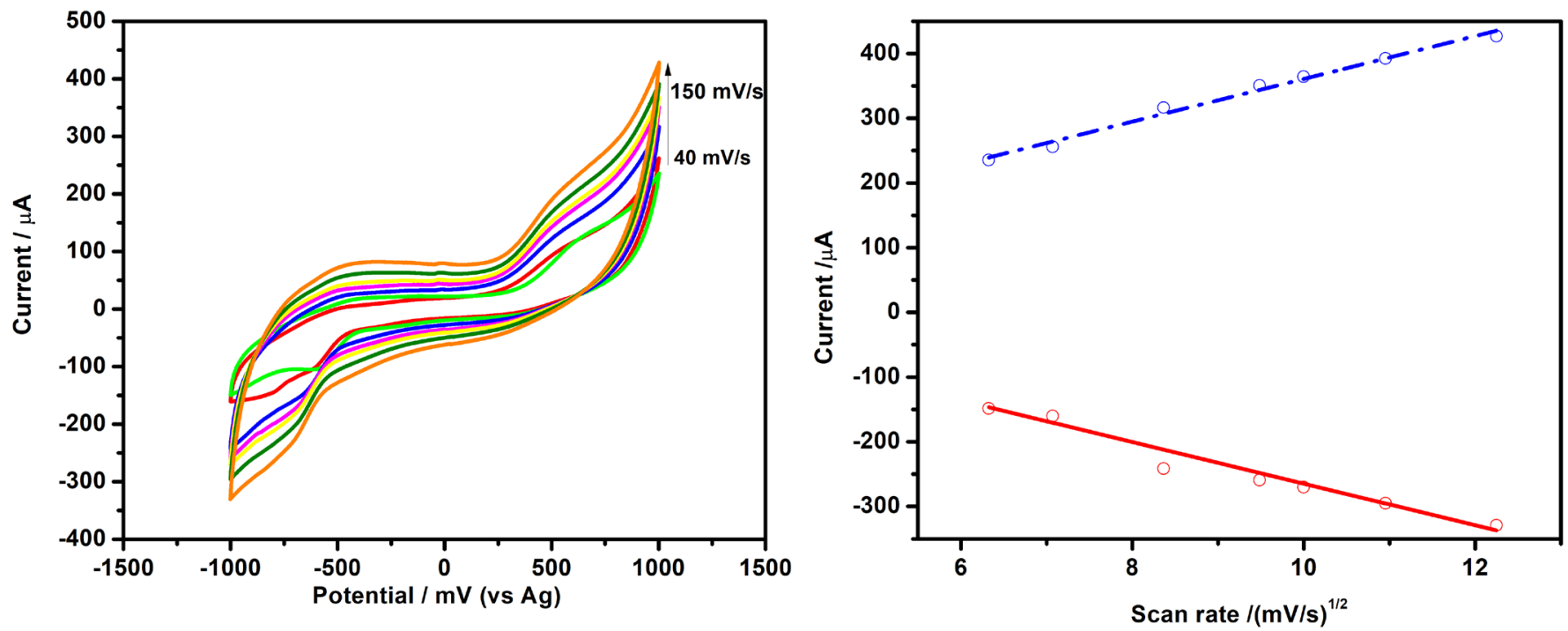

Figure 3. (A) Cyclic voltammograms of modified SPCNE at different scan rates from 40 to $150 \mathrm{mVs}^{-1}$. (B) Anodic (red dashed line) and cathodic current (blue dashed line). 


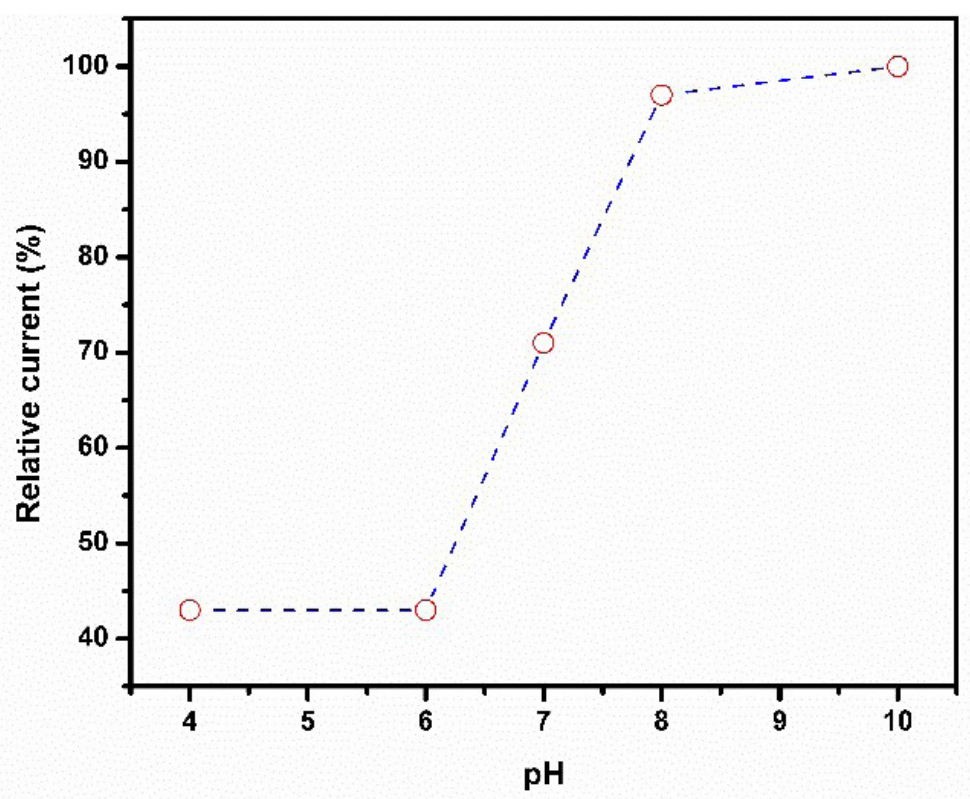

Figure 4. Effect of the $\mathrm{pH}$ value on the oxidation current signal of triclosan.

Peroxidases contain heme groups that mediate the single electron oxidation of phenolic compounds in the presence of hydrogen peroxide. The electron generated can migrate to the electrode's surface producing a current signal that can be used to detect TCS.

To date, no previous studies have investigated the role of peroxidases, let alone a guinea grass peroxidase, to detect TCS molecules in the presence of $\mathrm{H}_{2} \mathrm{O}_{2}$. In this study, we also carried out chronoamperometric measurements to monitor the current reduction signal of our GGP-modified electrode with different $\mathrm{H}_{2} \mathrm{O}_{2}$ concentrations. We obtained a current-time plot for our GGP biosensor after successive additions of $0.3 \mathrm{mM} \mathrm{H}_{2} \mathrm{O}_{2}$ to $7 \mathrm{~mL}$ of $\mathrm{PBS}(\mathrm{pH} \mathrm{8.0)}$ at an applied potential of $-791 \mathrm{mV}$ (Fig. 5A). The GGP at the electrode's surface showed an electrocatalytic reduction with stable values upon peroxide addition to the PBS solution, revealing a fast electron transfer communication between the redox center of the GGP and the carbon nanotube electrode surface. Furthermore, as shown in Fig. 5B, we observed a linear response of the biosensor when the concentration of the $\mathrm{H}_{2} \mathrm{O}_{2}$ solution varied from 0.1 $\mathrm{mM}$ to $3.3 \mathrm{mM}$. The bottom detection limit was $99 \mu \mathrm{M}$ (signal to noise ratio $\mathrm{S} / \mathrm{N}=3$ ) with a sensitivity of $34.5 \mathrm{nA} / \mathrm{M}$. None of the control experiments, with the electrode without GGP, at $-791 \mathrm{mV}$ (vs Ag) exhibited signals after the addition of $\mathrm{H}_{2} \mathrm{O}_{2}$ (Fig. $5 \mathrm{~A}$, red line).

The chronoamperometric measurements for the GGP-modified electrode at an applied potential of $370 \mathrm{mV}$, after successive additions of $10 \mu \mathrm{M}$ TCS to $7 \mathrm{~mL}$ PBS ( $\mathrm{pH} \mathrm{8.0)}$ with $5 \mathrm{mM} \mathrm{H}_{2} \mathrm{O}_{2}$, revealed that the oxidation current 

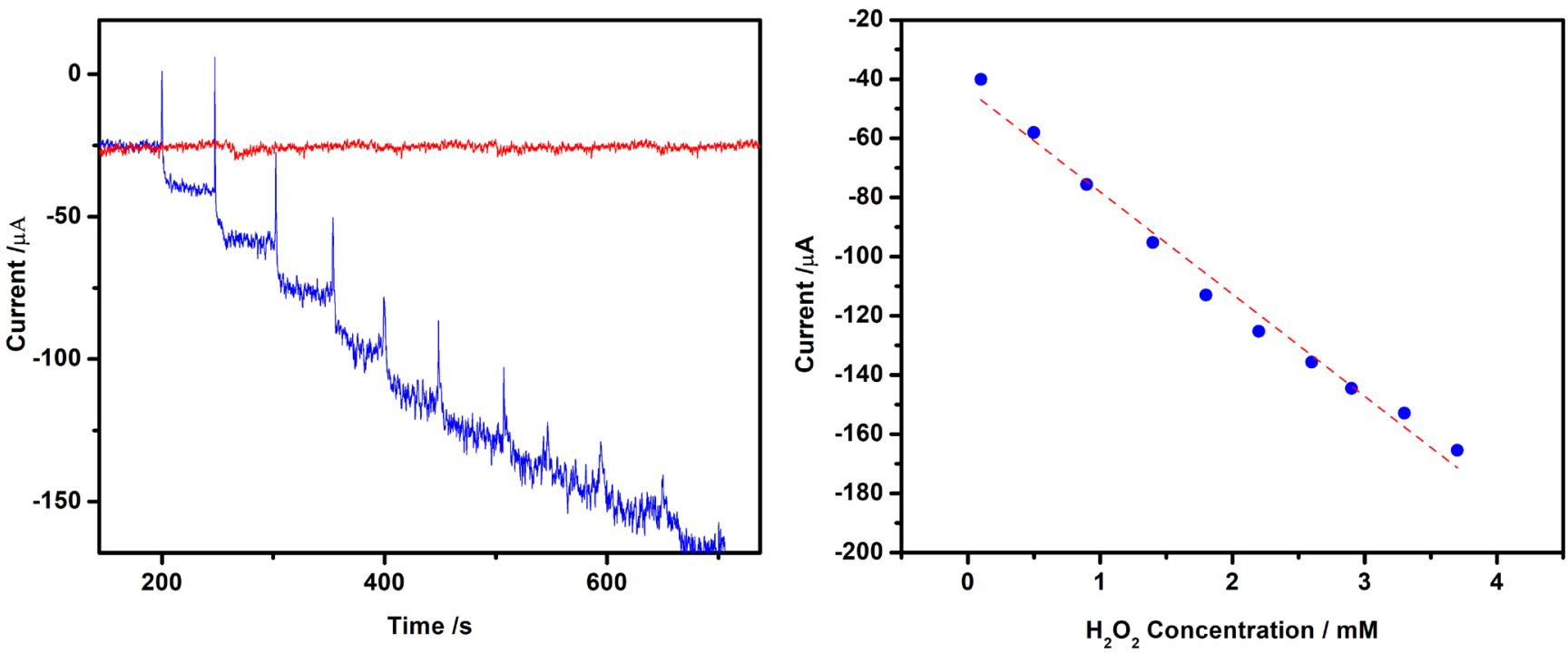

Figure 5. (A) Amperometric response of SPCN (red) and GGP-modified SPCN (blue) electrodes to sequential additions of $0.3 \mathrm{mM} \mathrm{H}_{2} \mathrm{O}_{2}$ to a $10 \mathrm{mM}$ PBS pH 8.0 solution, $\mathrm{E}=-791 \mathrm{mV}$ vs Ag. (B) Average current response of SPCNE/GGP electrode as a function of $\mathrm{H}_{2} \mathrm{O}_{2}$ concentration.

signal increased in proportion to the concentration of TCS (Fig. 6A). A linear behavior was obtained for the TCS concentration range of $20 \mu \mathrm{M}$ to $80 \mu \mathrm{M}$, and the resulting linear regression equation was $I \mu \mathrm{A})=0.0249(\mu \mathrm{M})+8.43$ $\left(\mathrm{R}^{2}=0.995\right)$ with a detection limit of $3 \mu \mathrm{M}$ at $\mathrm{S} / \mathrm{N}=3$ (Fig. 6B).

The stability of the GGP-modified SPCNE was evaluated with 13 continuous cyclic scans. No appreciable variation was observed in the voltammetric waves (Suppl. 2.). Furthermore, after storing the electrodes at $4{ }^{\circ} \mathrm{C}$ for three weeks, the GGP-modified electrode retained its bioelectrocatalytic activity, as evidenced by the values in the amperometric current signal being close to the initial current response. This long-term stability could be attributed to the strong interaction between the carbon nanotubes and the amino and carboxylic groups of the GGP.

After the sequential addition of $o$-nitrophenol, ascorbic acid, and glucose (1 $\mathrm{mM}$ each), no outstanding interference signals were observed on the TCS detection performance of the GGP-modified SPCNTE (Fig. 7). This result suggests that the tested biosensor has a high selectivity and specificity for TCS.

We evaluated our analytical application with environmental samples, immersing our GGP-modified SPCNE in three different concentrations of TCS in tap water, revealing a linear trend in current response as TCS concertation increased (Fig. 8). These results showed that satisfactory recovery 

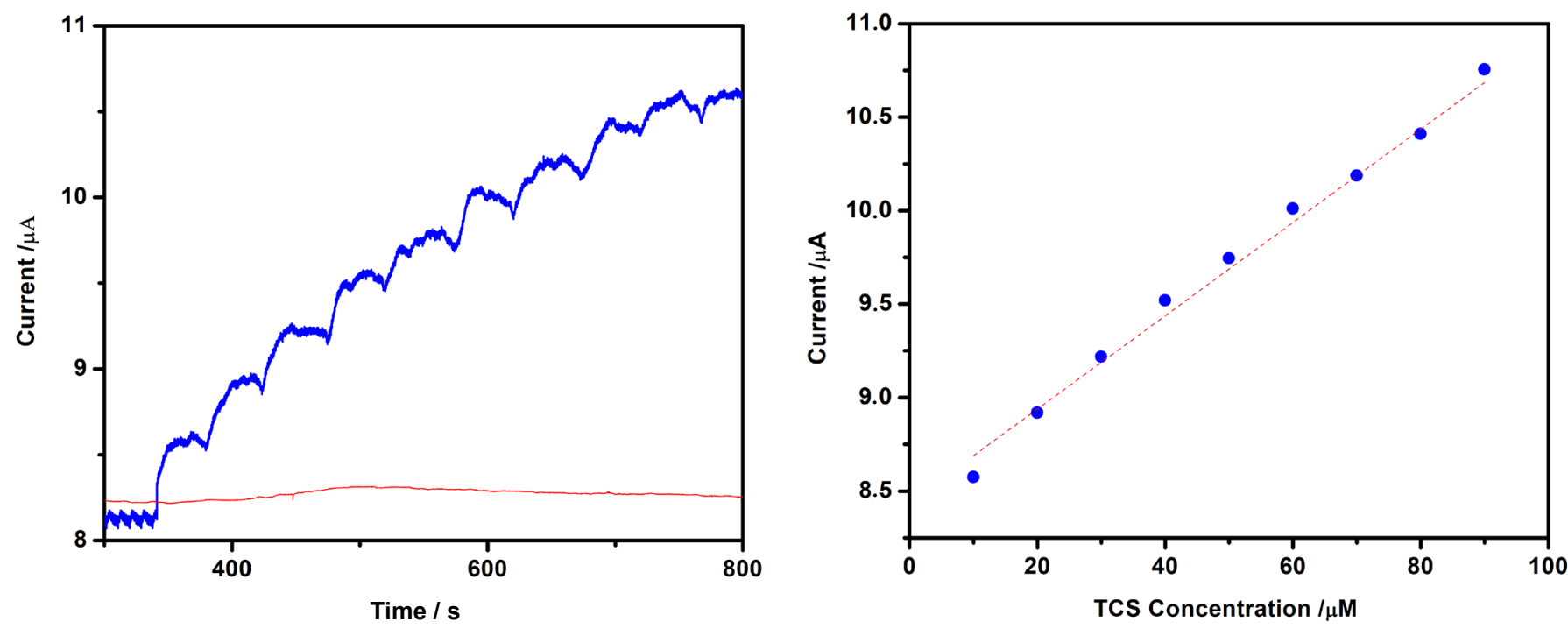

Figure 6. (A) Amperometric response of the SPCN (red) and the GGP-modified SPCN (blue) electrodes to subsequent additions of $10 \mu \mathrm{M}$ triclosan to a $10 \mathrm{mM}$ PBS ( $\mathrm{pH} \mathrm{8.0)}+5 \mathrm{mM} \mathrm{H}_{2} \mathrm{O}_{2}$ solution. $\mathrm{E}=370 \mathrm{mV}$ vs Ag. (B) Average current response of the GGP-modified SPCNE as a function of the TCS concentration.

of TCS could be obtained using our GGP-modified SPCNE indicating that our sensor could be used as an interesting bioanalytical tool for sensing TCS and phenol related compounds in water samples.

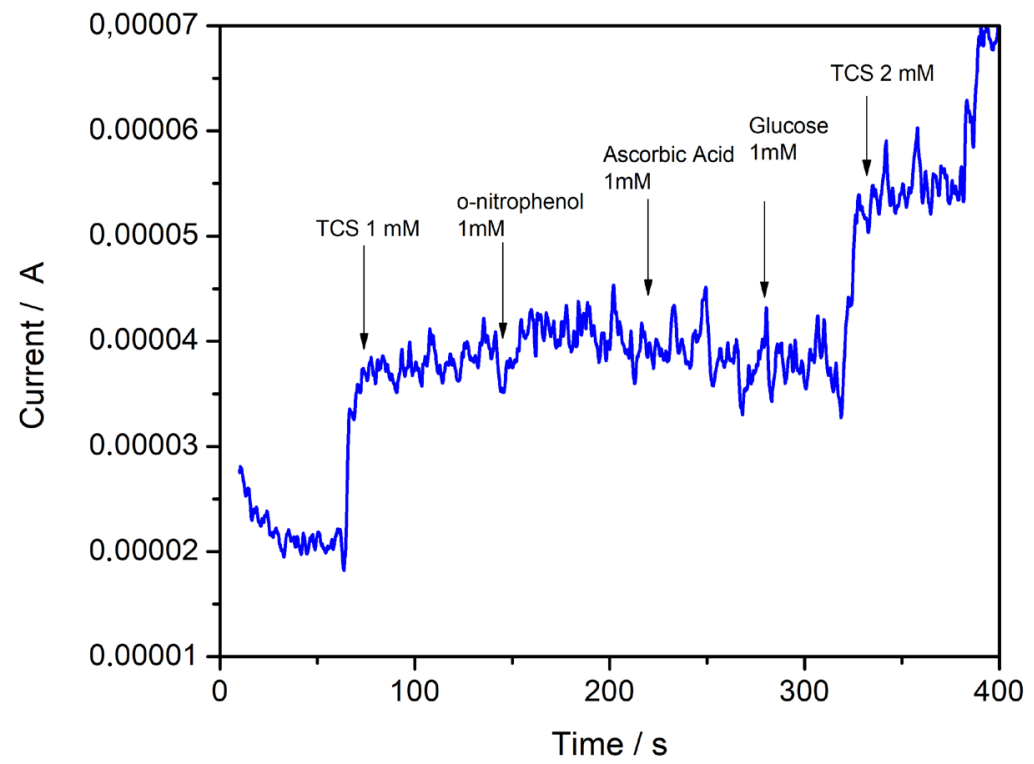

Figure 7. Chronoamperometric response of the GGP-modified SPCNE, at 370 $\mathrm{mV}$, in the presence of different concentration of TCS, o-nitrophenol, ascorbic acid, and glucose. 
Table 2. Electrochemical detection of TCS in tap water samples ( $\mathrm{n}=3$ electrodes)

\begin{tabular}{ccccc}
\hline $\begin{array}{c}\text { Sample } \\
\text { No. }\end{array}$ & $\begin{array}{c}\text { Current } \\
(\mu \mathbf{A})\end{array}$ & $\begin{array}{c}\text { TCS added } \\
(\mu \mathbf{M})\end{array}$ & $\begin{array}{c}\text { TCS detected } \\
(\mu \mathbf{M})\end{array}$ & $\begin{array}{c}\text { Recovery } \\
(\mathbf{\%})\end{array}$ \\
\hline 1 & 8.46 & 3 & 5 & 60 \\
\hline 2 & 8.78 & 9 & 12 & 75 \\
\hline 3 & 8.95 & 19 & 22 & 86 \\
\hline
\end{tabular}

To the best of our knowledge, this is the first study that involves a plant peroxidase integrated in a carbon nanotube screen-printed electrode to detect TCS. Consequently, this GGP-modified SPCNTE is a potential bioanalytical platform for environmental samples.

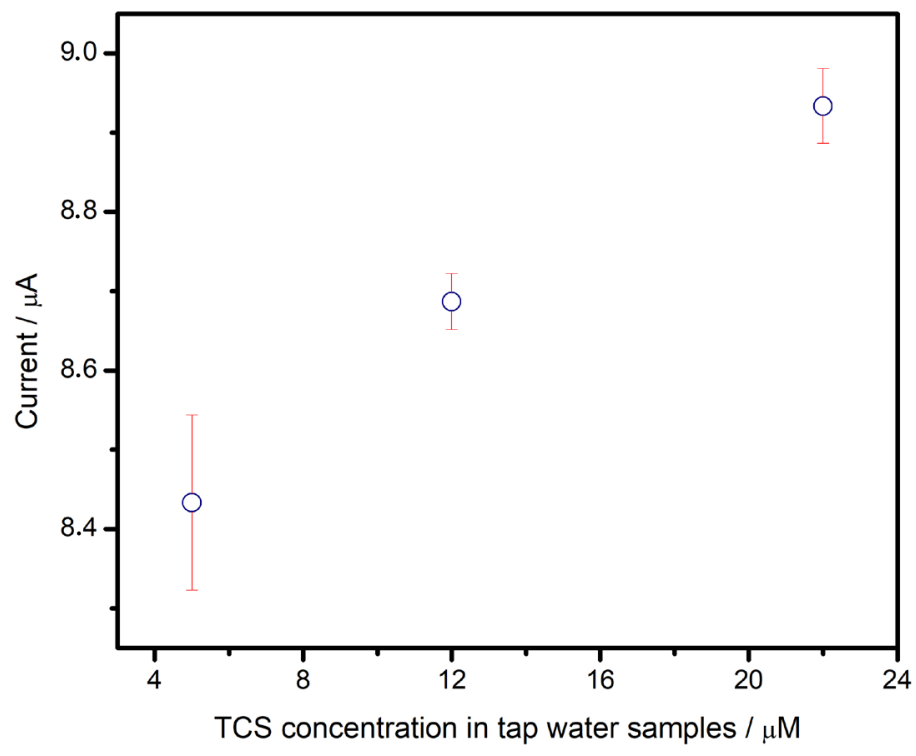

Figure 8. Current response of SPCNE/GGP electrode at $370 \mathrm{mV}$ as a function of TCS concentration in tap water samples.

\section{Conclusions}

A new amperometric biosensor was developed through the modification of the electrode surface of a screen-printed carbon nanotube electrode with a highly stable peroxidase from guinea grass leaves in order to detect triclosan. 
The resulting biosensor showed a swift electronic communication and a good performance towards hydrogen peroxide reduction and triclosan oxidation. This GGP-modified electrode features wide linearity, high sensitivity, and a redox potential of -791 and $370 \mathrm{mV}$. Thus, this new amperometric detection system becomes a promising and potential bioanalytical tool for the in situ analysis of samples of environmental interest.

\section{Acknowledgements}

The authors acknowledge the financial support provided by Universidad Industrial de Santander-Vicerrectoría de Investigación y Extensión through its funding initiatives: "Capital Semilla” (Research Grant 1735), "Proyecto de Convocatoria Interna” (Grant No. 5762), and “Estancias postdoctorales”.

\section{Conflict of interest}

The authors have no conflict of interest to declare.

\section{References}

Alemzadeh I, Nejati S. Phenols removal by immobilized horseradish peroxidase, Journal of Hazardous Materials, 166: 1082-1086, 2009. doi: 10.1016/j.jhazmat.2008.12.026

Besharati M, Saboury A, Poostchi A, Rashidi A. Stability and activity improvement of horseradish peroxidase by covalent immobilization on functionalized reduced graphene oxide and biodegradation of high phenol concentration, International Journal of Biological Macromolecules, 106: 1314-1322, 2018.

doi: 10.1016/j.ijbiomac.2017.08.133

Bradford M. A rapid and sensitive method for the quantitation of microgram quantities of protein utilizing the principle of proteindye binding, Analytical Biochemestry, 72: 248-254, 1976.

doi: 10.1016/0003-2697(76)90527-3

BrusovaZ, FerapontovaEE, SakharovY, MagnerE. Bioelectrocatalysis of Plant Peroxidases Immobilized on Graphite in Aqueous and Mixed Solvent Media, Electroanalysis, 17: 460-468, 2005.

doi: 10.1002/elan.200403182 
Centeno D, Solano X, Castillo J. A new peroxidase from leaves of guinea grass (Panicum maximum): A potential biocatalyst to build amperometric biosensors, Bioelectrochemistry, 116: 33-38, 2017

doi: 10.1016/j.bioelechem.2017.03.005

Dai H, Xu G, Gong L, Yang G, Lin Y, Tong Y, Chen J. Electrochemical detection of triclosan at a glassy carbon electrode modifies with carbon nanodots and chitosan, Electrochimica Acta, 80:362-367, 2012. doi: 10.1016/j.electacta.2012.07.032

Fotouhi L, Shahbaazi HR, Fatehi A, Heravi M. Voltammetric Determination of Triclosan in Waste Water and Personal Care Products, International Journal of Electrochemistry Science, 5: 13901398, 2010.

doi: $10.2010 /$ i.jes.2010.12

Gaspar S. Biosensors based on novel plant peroxidases: a comparative study, Electrochimica Acta, 46: 255-264, 2000.

doi: 10.1016/S0013-4686(00)00580-6

Guo J, Li X, Cao X, Li Y, Wang X, Xu X. Determination of triclosan, triclocarban and methyl-triclosan in aqueous samples by dispersive liquid - liquid microextraction combined with rapid liquid chromatography, Journal of Chromatography A, 1216: 3038-3043, 2009.

doi: 10.1016/j.chroma.2009.02.021

Huang J, Tsai Y. Chemical Direct electrochemistry and biosensing of hydrogen peroxide of horseradish peroxidase immobilized at multiwalled carbon nanotube/alumina-coated silica nanocomposite modified glassy carbon electrode, Sensors and Actuators B: Chemical, 140: 267-272, 2009.

doi: 10.4172/2155-6210.S9-001

Lenz A, Pattison C, Ma H. Triclosan and triclocarban induce systemic toxic effects in a model organism the nematode Caenorhabditis elegans, Environmental Pollution, 231: 462-470, 2017.

doi: 10.1016/j.envpol.2017.08.036

Li B, Qiu Z, Wan Q, Liu Y, Yang N. $\beta$-cyclodextrin functionalized graphene nano platelets for electrochemical determination of triclosan nano platelets for electrochemical determination of triclosan, Physics Status Solidi A, 5: 1-5, 2014.

doi: 10.1002/pssa.201431540 
Ozaki N, Nakazato A, Nakashima K, Kindaichi T, Ohashi A. Science of the Total Environment Loading and removal of PAHs, fragrance compounds, triclosan and toxicity by composting process from sewage sludge, Science of The Total Environment, 605: 860-866, 2017.

doi: 10.1016/j.scitotenv.2017.06.165

Rotariu L, Lagarde F, Jaffrezic-renault N, Bala C. Trends in Analytical Chemistry Electrochemical biosensors for fast detection of food contaminants - trends and perspective, Trends in Analytical Chemistry, 79: 80-87, 2016.

doi: 10.1016/j.trac.2015.12.017

Sakahrov I, Vorobiev A, Castillo J. Synthesis of polyelectrolyte complexes of polyaniline and sulfonated polystyrene by palm tree peroxidase, Enzyme and Microbial Technology, 33; 661-667, 2003.

doi: 10.1016/S0141-0229(03)00188-1

Shi Y, Liu X, Zhang J, Shao B. Analysis of triclosan and triclocarban in human nails using isotopic dilution liquid chromatography - tandem mass spectrometry, Journal of Chromatography B, 934: 97-101, 2013.

doi: 10.1016/j.jchromb.2013.07.003

Song S, Song QJ, Chen Z. Online phototransformation - flow injection chemiluminescence determination of triclosan, Analytical and Bioanalytical Chemistry, 387: 2917-2922, 2007.

doi: 10.1007/s00216-007-1130-5

Wang Y. An amperometric biosensor for hydrogen peroxide by adsorption of horseradish peroxidase onto single-walled carbon nanotubes, Colloids and Surfaces B: Biointerfaces, 90: 62-67, 2012.

doi: 10.1016/j.colsurfb.2011.09.045

Wu T, Li T, Liu Z, Guo Y, Dong C. Electrochemical sensor for sensitive detection of triclosan based on graphene/palladium nanoparticles hybrids, Talanta, 164: 556-562, 2017.

doi: 10.1016/j.talanta.2016.12.027

Yang J, Wang P, Zhang X. Electrochemical Sensor for Rapid Detection of Triclosan Using a Multiwall Carbon Nanotube Film, Journal of Agricultural and Food Chemistry, 57; 9403-9407, 2009. doi: 10.1021/jf902721r 


\section{Detección amperométrica de triclosan con electrodos de nanotubos de carbono impresos en pantalla modificados con peroxidasa de Pasto Guinea (Panicum maximum)}

Resumen: El triclosan es un compuesto con actividad antimicrobiana, ampliamente usado en productos para el consumidor. Por su bien documentada toxicidad, la cantidad de triclosan presente en diferentes productos debe ser estrictamente controlada. Este artículo describe un nuevo sensor amperométrico para la detección de triclosan, que consiste en un electrodo de nanotubos de carbón serigrafiado (Screenprinted carbon nanotube electrode-SPCNE) modificado con peroxidasa de pasto Guinea (GGP). A diferencia del SPCNE no modificado, el SPCNE modificado con GGP fue capaz de detectar una respuesta electroquímica mejorada del triclosan. Los voltamogramas cíclicos del SPCNE modificado con GGP en una solución de ferrocianuro de potasio mostraron un aumento en los valores de corriente y linealidad entre las velocidades de barrido y las corrientes de pico (máximas) de oxidación, lo cual sugiere un proceso de superficie controlada. El SPCNE modificado con GGP mostró una excelente actividad electrocatalítica para la oxidación del triclosan, a un potencial redox de $370 \mathrm{mV}$, en presencia de peróxido de hidrógeno, exhibiendo una respuesta lineal entre 20 y $80 \mathrm{mM}$ y un límite de detección de $3 \mu \mathrm{M}$. Este nuevo sistema amperométrico basado en nanotubos de carbón integrados con GGP se convierte en una herramienta potencial para el análisis ambiental y el control de calidad de alimentos.

Palabras clave: Biosensor amperométrico; nanotubos de carbón; peroxidasa de pasto Guinea; electrodos impresos en pantalla; Triclosan. 


\section{Detecçáo amperométrica de triclosan com eletrodos de nanotubos de carbono serigrafados modificados com peroxidase de capim-mombaça (Panicum maximum)}

Resumo: O triclosan é um composto com atividade antimicrobiana, amplamente utilizando em produtos para o consumidor. Devido a sua toxicidade bem documentada, o conteúdo de triclosan em diferentes produtos dever ser estritamente controlado. Este artigo apresenta um novo sensor amperométrico para a detecção de Triclosan, que consiste em um eletrodo de nanotubos de carbono serigrafado (Screen-printed carbon nanotube electrode - SPCNE) modificado com peroxidase de capim-mombaça (GGP). Diferentemente do SPCNE sem modificação, o SPCNE modificado com GGP foi capaz de detectar e melhorar a resposta eletroquímica do Triclosan. Os voltamogramas cíclicos de SPCNE modificados com GGP em uma solução de ferrocianeto de potássio mostraram um aumento dos valores de corrente e da relação entre a taxa de escaneio e da corrente do pico de oxidação, o que sugere com comportamento de processo de superfície controlada. O SPCNE modificado com GGP mostrou uma excelente atividade eletrocatalítica a oxidação do Triclosan, a um potencial redox de $370 \mathrm{mV}$, na presença de peróxido de hidrogênio, exibindo uma resposta linear entre 20 e $80 \mathrm{mM}$ e um limite de detecção de $3 \mu \mathrm{M}$. Este novo sistema amperométrico baseado em nanotubos de carbono integrados com GGP se converte em uma potencial ferramenta para a análise ambiental e o controle de qualidade de alimentos.

Palavras-chave: Biosensor amperométrico; nanotubos de carbono; peroxidase de capim-mombaça; eletrodos serigrafados; Triclosan. 


\section{Angie Orduz}

Angie Orduz is chemist from Industrial University of Santander, currently has a COCINET Doctoral Scholarships in Chemistry in The National University of South in Argentina. Angie is researching the preconcentration and removal of contaminants with adsorbent materials from biopolymers, carbon nanotubes and inorganic solids base on Inorganic and Analytical Chemistry.

ORCID: 0000-0002-7022-9535

\section{Jorge Gutierrez}

Jorge A. Gutierrez has a Ph.D in Chemistry Sciences and broad expertise in nanoscience and nanobiotechnology, he currently works at University of Quindío as teacher and researcher, developing projects related to synthesis and characterization of metallic, polymeric and semiconductor nanomaterials.

\section{Sergio Blanco}

Sergio Blanco currently works at the School of Metallurgical Engineering and Materials Science, Industrial University of Santander. Sergio does research in Electrochemistry and Materials Engineering, including the recovery of metal values and synthesis of functional materials from spent household batteries, development of nanostructured sensors, synthesis, and characterization of superhydrophobic and multifunctional coatings. ORCID: 0000-0003-2485-875X

\section{John Jairo Castillo León}

Chemist and Doctor in chemistry from Industrial University of Santander (Associate Professor) with a Postdoctorate in nanotechnology from Denmark Technical University. He is author and co-author of 28 specialised high impact journals and his research is focused on biosensors, bioelectronics and nanosciences.

ORCID: 0000-0002-6751-2305 